\title{
PENERAPAN PEMBELAJARAN BIOKIMIA BERBASIS STUDENT CENTER LEARNING (SCL)TERHADAP KEMAMPUAN PEMECAHAN MASALAH MAHASISWA
}

\author{
Lilis Lismaya \\ Program Studi Pendidikan Biologi FKIP \\ Universitas Kuningan
}

\begin{abstract}
Abstrak
Tujuan penelitian ini adalah untukmenganalisis perbedaan hasil antara tes awal dan tes akhir pada kemampuan pemecahan masalah sebelum dan sesudah pembelajaran biokimia berbasis Student Center Learning (SCL), menganalisis pengaruhpembelajaran Student Center Learning (SCL)terhadap kemampuan pemecahan masalah mahasiswa, dan mengungkap respon mahasiswa terhadap penerapan pembelajaran biokimia berbasisStudent Center Learning (SCL) terhadap kemampuanpemecahan masalah mahasiswa.Metode penelitian yang digunakan dalam penelitian ini adalah weak experimental atau eksperimen lemah dengan desain penelitian The One-Group Pretest-Posttest Design(Fraenkel,2007).Dalam penelitian ini hanya menggunakan 1 kelas eksperimen yang diberikan perlakuan untuk menilai pengaruh dari perlakuan tersebut, tanpa dibandingkan dengan kelas kontrol.Instrumen yang digunakan adalah soal kemampuan memecahkan masalah berisi indikator yang telah ditentukan dan angket respon mahasiswa. Hasil dari penelitian ini yaitu 1)Terdapat perbedaan hasil antara tes awal dan tes akhir pada keterampilan pemecahan masalah sebelum dan sesudah pembelajaran biokimia berbasis Student Center Learning (SCL) dengan rata-rata indeks gain 18,3 dan hasilnya lebih besar dari KKM yaitu $84,8>65$. 2)Terdapat pengaruh yang signifikan dari pembelajaran biokimia berbasis Student Center Learning (SCL) terhadap kemampuan pemecahan masalah dan penguasaan konsep mahasiswa. 3)Tingkat ketuntasan pemecahan masalah mahasiswa sebesar 70,8 \%. 29,2\% mahasiswa belum mencapai ketuntasan belajar. 4)Respon positif dari mahasiswa terhadap penerapan pembelajaran biokimia berbasis Student Center Learning (SCL).
\end{abstract}

Kata kunci: Biokimia, Kemampuan Pemecahan Masalah, Pembelajaran Berbasis SCL.

\section{PENDAHULUAN}

Sejauh ini pendidikan kita masih didominasi oleh pandangan bahwa pengetahuan merupakan seperangkat fakta-fakta yang harus dihafal. Kelas masih berfokus pada guru sebagai sumber utama pengetahuan, ceramah masih menjadi pilihan metode belajar. Untuk itu perlu adanya pembelajaran baru yang lebih memberdayakan siswa. Suatu pembelajaran yang mendorong siswa mengkonstruksi pengetahuan mereka sendiri, serta pembelajaran yang mampu menjadikan siswa siap menghadapi masalah-masalah nyata yang ada dalam kehidupan mereka. Oleh karena itu pembelajaran berbasis SCL diharapkan dapat menjadi salah satu pembelajaran yang cocok diterapkan dalam proses pembelajaran saat ini.

Pembelajaran berpusat pada siswa atau Student Centered Learning (SCL) merupakan pembelajaranyang menuntut partisipasi yang tinggi dari peserta didik, karena peserta didik menjadi pusat perhatian selama kegiatan belajar berlangsung. Pembelajaran SCL menuntut peran guru yang awalnya bersifat kaku instruksi menjadi memberi kesempatan kepada peserta didik untuk 
menyesuaikan dengan kemampuannya dan berperilaku secara langsung dalam menerima pengalaman belajarnya.

SCL juga diperlukan untuk mengantisipasi dan mengakomodasi perubahan dalam bidang sosial, politik, ekonomi, teknologi dan lingkungan, yang menyebabkan informasi dalam buku teks dan artikel-artikel yang ditulis lebih cepat kadaluarsa. Selain itu, di masa mendatang, dunia kerja membutuhkan tenaga kerja yang berpendidikan baik, yang mampu bekerja sama dalam tim, memiliki kemampuan memecahkan masalah secara efektif, mampu memproses dan memanfaatkan informasi, serta mampu memanfaatkan teknologi secara efektif dalam pasar global, dalam rangka meningkatkan produktivitas. Oleh sebab itu, proses pembelajaran harus difokuskan pada pemberdayaan dan peningkatan kemampuan mahasiswa dalam berbagai aspek ilmu pengetahuan, teknologi dan seni. Mahasiswa sebagai subyek pembelajaran, yang perlu diarahkan untuk belajar secara aktif membangun pengetahuan dan kemampuannya dengan cara bekerjasama dan berkolaborasi dengan berbagai pihak terkait.

Mata kuliah biokimia merupakan mata kuliah yang dianggap sulit oleh sebagian besar mahasiswa, sehingga butuh suatu cara penyampaian materi agar mudah dikuasai dan difahami oleh siswa. Melalui pembelajaran biokimia berbasis Student Center Learning (SCL) diharapkan siswa dapat lebih mudah dalam memecahkan permasalahan yang ada dalam biokimia. Salah satu konsep yang akan diteliti adalah konsep asam amino dan protein, meliputi reaksi kimia, analisis kimia, ciri struktur dan fungsi protein.

Tujuan dalam penelitian ini adalah untukmenganalisis perbedaan hasil antara tes awal dan tes akhir pada kemampuan pemecahan masalah sebelum dan sesudah pembelajaran biokimia berbasis Student Center Learning (SCL), menganalisis pengaruh pembelajaran Student Center Learning (SCL)terhadap kemampuan pemecahan masalah mahasiswa,mengungkap respon mahasiswa terhadap penerapan pembelajaran biokimia berbasisStudent Center Learning (SCL) terhadap kemampuanpemecahan masalah mahasiswa.

\section{METODE PENELITIAN}

Metode penelitian yang digunakan dalam penelitian ini adalah weak experimental atau eksperimen lemah dengan desain penelitian The One-Group Pretest-Posttest Design(Fraenkel,2007).Dalam penelitian ini hanya menggunakan kelas eksperimen yang diberikan perlakuan untuk menilai pengaruh dari perlakuan tersebut, tanpa dibandingkan dengan kelas kontrol.

Instrumen yang digunakan berupa soal kemampuan memecahkan masalah berisi indikator yang telah ditentukan. Soal diberikan sebelum dan sesudah pembelajaran. Sedangkan untuk mengetahui respon mahasiswa terhadap pembelajaran berbasis SCL diberikan angket di akhir pembelajaran.Melakukan pengolahan dan analisis data dengan uji statistik, kegiatan meliputi pemberian skor untuk pretest dan posttest, menghitung $N$ gain, analisis data menggunakan Software Statistical Package for Social Science (SPSS) for Windows versi 16.0, serta melakukan analisis kemampuan pemecahan masalahberdasarkan kategori kemampuan pemecahan masalahmahasiswa berdasarkan ketercapaian pada KKM. 


\section{HASIL dan PEMBAHASAN}

a. Pengaruh Pembelajaran Berbasis SCL Terhadap Kemampuan pemecahan masalah

Berikut ini pada Tabel 1. disajikan hasil rata-rata pre tes dan post tes kelas eksperimen.

Tabel 1. Hasil Rata-rata Pre tes dan PosttesKemampuan pemecahan masalah

\begin{tabular}{ccccc}
\hline & Jml & \multicolumn{3}{c}{ Rata-rata Kemampuan } \\
Kelas Uji Coba & $\begin{array}{c}\text { Maha } \\
\text { Siswa }\end{array}$ & $\begin{array}{c}\text { Pre } \\
\text { tes }\end{array}$ & $\begin{array}{c}\text { Post } \\
\text { tes }\end{array}$ & $\begin{array}{c}\text { Indeks } \\
\text { Gain }\end{array}$ \\
\hline $\begin{array}{c}\text { Kelas } \\
\text { Eksperimen } \\
\text { (mahasiswa }\end{array}$ & 26 & 65,1 & 90,5 & 25,4 \\
Tingkat 2) & & & & \\
\hline
\end{tabular}

Tabel 4.1 menunjukkan bahwa hasil rata-rata pretest kemampuan pemecahan masalah pada kelas eksperimen adalah 65,1 dan posttest 90,5 sedangkan indeks gain bernilai 25,4 . Hasil ini menunjukkan terdapat peningkatan kemampuan pemecahan masalah mahasiswa pada kelas eksperimen yang diberi perlakuan pembelajaran SCL yaitu melalui penggunaan model Problem Based Learning.Demikian juga untuk skor rata-rata indeks gain kemampuan pemecahan masalah pada kelas eksperimen $25,4 \%$ atau 0,25 , termasuk kategori rendah. Hal ini menunjukkan bahwa kemampuan pemecahanmasalah mahasiswa setelah mengikuti pembelajaran berbasis $S C L$ mengalami peningkatan. Walaupun nilai indeks gainnya termasuk kategori rendah, namun hasil ini cukup signifikan membuktikan bahwa penggunaan pembelajaran SCL pada mata kuliah biokimia dapat meningkatkan kemampuan pemecahan masalah mahasiswa. Terlebih jika dibandingkan dengan Kriteria Ketuntasan Minimal (KKM) mahasiswa untuk konsep protein ini adalah 65 , maka hasil post test ini lebih tinggi dibandingkan dengan nilai KKM tersebut. Hasil analisis kemampuan pemecahan masalah mahasiswa berdasarkan nilai pre test dan post tes dapat juga dilihat pada Gambar 1.

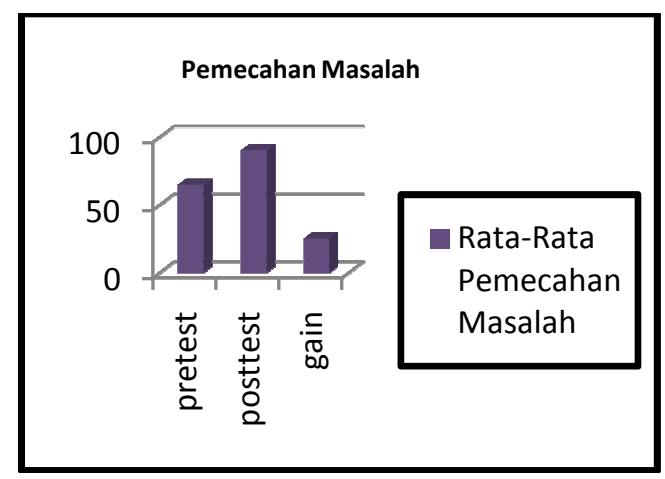

Gambar 1. Hasil Rata-rata Tes Kemampuan pemecahan masalah Mahasiswa

Dilakukan uji normalitas dan homogenitas terhadap pre test, post test dan indeks gain kemampuan pemecahan masalah mahasiswa. Uji normalitas dan homogenitas digunakan sebagai prasyarat untuk uji statistik berikutnya.

Hasil pengujian normalitas data dengan Kolmogorov-Smirnov diperoleh hasil normal, baik data pretest, posttest maupun indeks gain. artinyakelas yang digunakan dalam penelitian ini berasal dari populasi yang terdistribusi normal dengan P-value lebih besar atau sama dengan $\alpha=0,05$.

Hasil Levene's Test uji homogenitasdata pre test, post test kemampuan pemecahan masalah mahasiswa disajikan pada Tabel 2.

Tabel 2. Hasil Uji Homogenitas Skor test Kemampuan Pemecahan Masalah

\begin{tabular}{ccccc}
\hline & & \multicolumn{3}{c}{ Kemampuan Pemecahan Masalah } \\
\cline { 3 - 5 } Data & N & $\begin{array}{c}\text { P- } \\
\text { value }\end{array}$ & A & Kesimpulan \\
\hline $\begin{array}{c}\text { Pre } \\
\text { test } \\
\text { Post } \\
\text { test }\end{array}$ & 26 & 0,93 & 0,05 & Homogen \\
\hline
\end{tabular}


Berdasarkan Tabel 4.2 diketahui bahwa skor pre test dan post test kemampuan pemecahan masalah mahasiswa pada taraf signifikansi $\alpha=$ 0,05 memenuhi kriteria $\mathrm{P}$-value $\geq \alpha=$ 0,05 , hal ini berarti bahwa varians data pre test dan post test adalah homogen.

Dari hasil pengujian statistik, data yang diperoleh berdistribusi normal dan homogen maka pengujian hipotesisnya dilakukan dengan uji statistik parametrik uji t Sample Independent Test. Hasil pengujian dengan uji $\mathrm{t}$ kemampuan pemecahan masalah selengkapnya dapat dilihat pada Tabel 3.

Tabel 3. Hasil Analisis Uji-t KemampuanPemecahan Masalah

\begin{tabular}{cccccc}
\hline $\begin{array}{c}\text { Sumber } \\
\text { data }\end{array}$ & $\begin{array}{c}\text { Skor } \\
\text { rerata }\end{array}$ & $\begin{array}{c}\text { Std. } \\
\text { Deviasi }\end{array}$ & $\begin{array}{c}\text { Signi } \\
\text { fikan } \\
\text { si }\end{array}$ & $\alpha$ & $\begin{array}{c}\text { Kepu } \\
\text { tusan }\end{array}$ \\
\hline Post test & 90,5 & 5,07 & 0,05 & $\begin{array}{c}0,0 \\
5\end{array}$ & $\begin{array}{c}\text { Teri } \\
\text { ma H }\end{array}$ \\
$\begin{array}{c}\text { Indeks } \\
\text { gain }\end{array}$ & 25,38 & 3,74 & 0,73 & $\begin{array}{c}0,0 \\
5\end{array}$ & $\begin{array}{c}\text { Teri } \\
\text { ma H }\end{array}$ \\
\end{tabular}

Berdasarkan Tabel 3. dapat diketahui bahwa hasil uji $\mathrm{t}$ menunjukkan signifikansi $0,00<\alpha(\alpha=$ $0,05)$, sehingga dapat disimpulkan bahwa terdapat pengaruh yang signifikan dari pembelajaran biokimia berbasis SCL terhadap kemampuan pemecahan masalah mahasiswa.

Berdasarkan hasil analisis data di atas, yaitu nilai indeks gain menunjukkan kriteria rendah yang artinya terdapat peningkatan kemampuan pemecahan masalah pada kelas yang diteliti, dan hasil uji $t$ menunjukkan penerimaan $\mathrm{H}_{1}$ Kedua hal tersebut menunjukkan bahwa terdapat pengaruh pembelajaran berbasis $S C L$ terhadap kemampuan pemecahan masalah mahasiswa pada konsep protein.

\section{Analisis Kategori Kemampuan Pemecahan Masalah}

Hasil tes mahasiswa diprosentase berdasarkan masingmasing indikator kemudian dimasukkan ke dalam tabel kategori kemampuan pemecahan masalah. Hasil prosentase masing-masing indikator kemampuan pemecahan masalah dapat dilihat pada Tabel 4.

Tabel 4. Rekap Kemampuan Pemecahan Masalah Mahasiswa

\begin{tabular}{lc}
\hline \multicolumn{1}{c}{ Tahap Dalam Proses } & $\begin{array}{c}\text { Pencapaian } \\
\text { Kelas }\end{array}$ \\
\hline $\begin{array}{l}\text { Mengidentifikasi masalah } \\
\text { Mengumpulkan dan } \\
\text { menganalisis data }\end{array}$ & $75 \%$ \\
$\begin{array}{l}\text { Menentukan alternatif } \\
\text { pemecahan masalah }\end{array}$ & $70 \%$ \\
$\begin{array}{l}\text { Merancang tindakan pemecahan } \\
\text { masalah } \\
\text { Mengevaluasi pemecahan } \\
\text { masalah. }\end{array}$ & $73 \%$ \\
\end{tabular}

Berdasarkan tabel 4. hasil ratarata prosentase kemampuan pemecahan masalah mahasiswa tiap indikator menunjukkan hasil yang lebih tinggi jika dibandingkan dengan KKM yaitu 65.

Berdasarkan Tabel 4. dapat dilihat prosentase ketuntasan belajar mahasiswa. Secara klasikal dapat dihitung prosentase tingkat ketuntasan yang diperoleh mahasiswa dalam hal pemecahan masalah yaitu mencapai $70,8 \%$ mahasiswa tuntas dalam belajar, sedangkan sisanya sebesar 29,2\% mahasiswa masih belum dikategorikan tuntas dalam belajar karena belum mencapai standar ketuntasan minimum dalam belajar.

Untuk dapat menerapkan pembelajaran Student Center Learning (SCL), dapat dilakukan dengan menggunakan metode-metode atau 
model-model belajar seperti small group discussion, simulation, case study, discovery learning (DL), self directed (learning (SDL), cooperative learning $(C L)$, collaborative learning $(C B L)$, contextual instruction (CI), project based learning (PJBL) dan Problem based learning (PBM).

Dalam pembelajaran berbasis masalah, terlihat adanya interaksi antar mahasiswa, mereka saling membantu, mau bekerja sama dan saling memberikan pendapat. Interaksi sosial ini menjadi salah satu karakteristik dalam pembelajaran berbasis masalah. Hal ini senada dengan apa yang dikemukakan oleh Vygotsky (Arends, 2008) bahwa interaksi sosial dalam belajar merupakan faktor yang turut mendukung pembentukan pengetahuan baru bagi individu. Vygotsky juga menekankan pentingnya aspek sosial belajar, karena itu interaksi sosial dengan orang lain akan membantu percepatan pengkonstruksian pengetahuan dan ide-ide baru.

$$
\text { Perbedaan peningkatan }
$$

pemecahan masalah pada setiap kriteriamelalui penggunanaan pembelajaran berbasis SCL yaitu pendekatan pembelajaran yang berpusat pada mahasiswa dalam hal ini model pembelajaran berbasis masalah dengan kegiatan pembelajaran yang lebihmengaktifkan mahasiswa dimana konsep-konsep dipelajari dan ditemukan sendiri oleh mahasiswa melalui kegiatan penyelidikan, sehingga pembelajaran menjadi lebih bermakna. Hal ini senada dengan apa yang dikemukakan oleh Piaget (Arends, 2008) bahwa pembelajaran harus melibatkan penyodoran berbagai situasi dimana anak biasa bereksperimen atau mengujicobakan berbagai hal untuk melihat apa yang terjadi, memanipulasi benda-benda, simbol-simbol, melontarkan pertanyaan dan mencari jawabannya sendiri, merekonsiliasikan apa yang ditemukannya pada suatu waktu dengan apa yang ditemukannya pada waktu yang lain, membandingkan temuannya dengan temuan anak-anak lain.

Pembelajaran berbasis masalah merupakan rangkaian aktivitas pembelajaran yang menekankan kepada proses penyelesaian masalah yang dihadapi secara ilmiah (Sanjaya, 2008). Ciri utama dari PBM adalah PBM merupakan rangkaian aktivitas pembelajaran, artinya dalam implementasi PBM ada sejumlah kegiatan yang harus dilakukan mahasiswa. PBM tidak mengharapkan mahasiswa hanya sekadar mendengarkan, mencatat, kemudian menghafal materi pelajaran, akan tetapi melalui PBM mahasiswa aktif berpikir, berkomunikasi, mencari dan mengolah data, dan akhirnya menyimpulkan, agar mahasiswa tidak hanya sekedar dapat mengingat materi pelajaran, akan tetapi menguasai dan memahami secara penuh, permasalahan substansi bahan ajar yang akan dipelajari. Dengan demikian mahasiswa menjadi lebih kuat pemahamannya terhadap konsep yang diajarkan oleh dosen dalam proses pembelajaran.

Pembelajaran Berbasis Masalah (PBM) memberikan pengaruh yang baik terhadap kemampuan pemecahan masalah mahasiswa karena pembelajaran Berbasis Masalah lebih mengarahkan mahasiswa untuk dapat berperan aktif membangun konsep dan menyelaraskan dengan pengetahuan awal yang sudah dimiliki. PBM memberikan kesempatan yang luaskepada mahasiswa untuk mengembangkan pemikirannya, pemecahan masalah, dan kecakapan intelektualnya, belajar berperan sebagai orang dewasa dengan pengalaman nyata atau situasi yang disesuaikan, dan 
menjadi mahasiswa yang mandiri (Delisle, 1997).

Dalam PBM mahasiswa juga dilatih untuk saling berinteraksi dengan yang lain, hal ini sesuai dengan pendapat Bruner (Arends, 2008) yang mengatakan bahwa interaksi sosial dalam pembelajaran sangat penting, karena interaksi sosial baik di dalam kelas maupun di luar kelas akan memberikan perolehan bahasa dan caracara mengatasi masalah bagi mahasiswa, tetapi interaksi yang dimaksudkan di sini bukan hanya sekedar interaksi lepas tanpa arah, tetapi interaksi yang memerlukan bimbingan dosen dan arahan dari orang yang lebih mampu. Alasan-alasan tersebut menjadi faktor penyebab PBM memberikan pengaruh yang baik dalam meningkatkan kemampuan pemecahan masalah mahasiswa.

Aktivitas pembelajaran PBM diarahkan untuk menyelesaikan masalah. PBM menempatkan masalah sebagai kata kunci dari proses pembelajaran. Artinya, tanpa masalah maka tidak mungkin ada proses pembelajaran, dimana pemecahan masalah dilakukan dengan menggunakan pendekatan berpikir secara ilmiah. Berpikir dengan menggunakan metode ilmiah adalah proses berpikir deduktif dan induktif. Proses berpikir ini dilakukan secara sistematis dan empiris. Sistematis artinya berpikir ilmiah dilakukan melalui tahapan-tahapan tertentu; sedangkan empiris artinya proses penyelesaian masalah didasarkan pada data dan fakta yang jelas. Hal tersebut sesuai dengan proses pembelajaran di kelas eksperimen dimana mahasiswa difasilitasi untuk mengembangkan kemampuan pemecahan masalahnya melalui permasalahan tentang macammacam kegiatan manusia yang dapat menyebabkan proses denaturasi protein yang dihadirkan dan menyelesaikan permasalahan tersebut dengan berpikir ilmiah.

$\begin{array}{ccr}\text { Hasil } & \text { tes } & \text { kemampuan } \\ \text { pemecahan } & \text { masalah } & \text { mahasiswa }\end{array}$ dilakukan analisis dengan cara menghitung prosentase setiap indikator kemampuan pemecahan masalah dan mengkategorikannya berdasarkan klasifikasi kemampuan pemecahan masalah. Prosentase indikator kemampuan pemecahan masalah menunjukkan hasil rata-rata yang cukup tinggi.

Untuk tahapan mengidentifikasi masalah, pencapaian kelas sebesar $75 \%$. Artinya dalam tahapan ini sebagian besar mahasiswa masih mampu mengidentiifkasi permasalahan yang disajikan, mampu memilah mana yang menjadi inti permasalahan dari setiap kasus yang disajikan, sisanya sebesar $25 \%$ mahasiswa masih belum dapat mengidentifikasi masalah dengan tepat. Kemudian pada tahap selanjutnya yaitu tahap mengumpulkan dan menganalisis data, pencapaian kelas mencapai $70 \%$, sisanya sebanyak $30 \%$ mahasiswa masih belum dapat mengumpulkan dan menganalisis data dengan tepat, hal ini dapat disebabkan karena kurangnya kemampuan mahasiswa dalam mengidentifikasi masalah sehingga dalam tahap mengumpulkan dan menganalisis data sebagian mahasiswa mengalami kesulitan.

Tahap pemecahan masalah selanjutnya adalah menentukan alternatif pemecahan masalah. Pada tahap ini pencapaian kelas mencapai $73 \%$, artinya ada $27 \%$ mahasiswa yang masih belum mampu menentukan alternatif pemecahan masalah dengan tepat. Hal ini dapat disebabkan karena kurangnya kemampuan mahasiswa dalam menganalisis data sehingga dalam menentukan alternatif pemecahan masalahpun mengalami kesulitan. 
Untuk tahap merancang tindakan pemecahan masalah pencapaian kelas sekitar $68 \%$, dan sisanya sebanyak $32 \%$ masih belum dapat merancang tindakan pemecahan masalah dengan tepat sesuai dengan masalah yang teridentifikasi. Tahap ini memang membutuhkan kemampuan pemikiran lebih tinggi dibanding tahap sebelumnya, karena mahasiswa benar-benar dituntut untuk dapat merancang tindakan pemecahan masalah yang tepat.

Tahap selanjutnya adalah mengevaluasi pemecahan masalah. Tahap ini juga membutuhkan tingkat pemikiran yang lebih tinggi dari tahaptahap sebelumnya. Karena pada tahap ini mahasiswa harus mampu menimbang akibat positif dan negatif dari pemecahan masalah yang diajukan berdasarkan kasus permasalahan. Untuk tahap ini pencapaian kelas mencapai $68 \%$, dan sisanya $32 \%$ mahasiswa masih belum mampu mengevaluasi pemecahan masalah yang mereka ambil.

Pencapaian kelas ini tentu dipengaruhi oleh banyak hal baik oleh faktor internal yang ada pada diri mahasiswa itu sendiri ataupun faktor eksternal yang berada di luar diri mahasiswa itu sendiri yaitu faktor lingkungan, salah satunya mahasiswa masih belum terbiasa melaksanakan pembelajaran berbasis masalah, mahasiswa belum terbiasa menganalisis masalah yang terjadi di kehidupan mereka yang berhubungan dengan konsep biologi yang mereka peroleh di ruang kelas.

Hal ini penulis sadari sepenuhnya bahwa pencapaian kelas yang belum mencapai kriteria ketuntasan minimal ini perlu mendapat dorongan dari berbagai pihak salah satunya adalah dosen. Mengapa faktor dosen ini sangat berpengaruh terhadap pencapaian mahasiswa? Hal ini tentu karena dosenlah yang bertanggung jawab memfasilitasi jalannya proses KBM di dalam kelas. Namun, terlepas dari itu, hasil pencapaian kelas ini sebagian besar sudah berada di atas nilai KKM yang ditentukan yaitu 65 untuk matakuliah biokimia khususnya materi protein. Walaupun perbedaan nilai pencapaian dengan KKM tidak terlalu jauh, namun hal ini menunjukkan adanya pengaruh dari pembelajaran yang digunakan dalam pembelajaran di kelas. Selain itu terlihat bahwa penerapan pembelajaran berbasis masalah ini mampu meningkatkan kemampuan mahasiswa dalam memecahkan masalah.

Hal ini sesuai dengan dukungan teoritis John Dewey (Arends, 2008) yang menyatakan bahwa PBM membuat peserta didik berpikir, menyelesaikan masalah, dan menjadi pelajar yang otonom. Pembelajaran di sekolah seharusnya purposeful (memiliki maksud yang jelas) dan tidak abstrak, dapat diselesaikan dengan sebaik-baiknyadengan memerintahkan anak-anak dalam kelompok-kelompok kecil untuk menangani proyek-proyek yang mereka minati dan mereka pilih sendiri. Visi pembelajaran yang purposeful dan problem-centered (dipusatkan pada masalah) yang didukung oleh hasrat bawaan siswa untuk mengeksplorasi situasi-situasi yang secara personal berarti baginya jelas berhubungan dengan PBM.

Dengan penerapan pembelajaran berbasis masalah, mahasiswa dituntun untuk mengembangkan kemampuan berpikirnya dalam memahami dan menentukan persamaan dan perbedaan sesuatu, memberikan alasan terhadap sesuatu hal dan menyimpulkan suatu pola atau hubungan antar variabel pada konsep tertentu. Hal ini sesuai dengan Barrows (1980) yang menyatakan bahwa pembelajaran berbasis masalah sebagai model belajar yang 
mengutamakan proses belajar dapat digunakan untuk melatih dan mengembangkan berbagai kemampuan dan kecakapan sains tingkat tinggi.

PBM dirancang untuk membantu mahasiswa mengembangkan pemikirannya, pemecahan masalah, dan kecakapan intelektualnya; belajar berperan orang dewasa dengan pengalaman nyata atau situasi yang disesuaikan/disumulasikan; dan menjadi pelajar yang independen/mandiri (Delisle, 1997). Hasting (2001) mengemukakan PBM dapat merangsang siswa untuk berpikir tingkat tinggi, termasuk di dalamnya belajar bagaimana belajar. Wang, Thomson, and Shuler (1998) mengemukakan PBM dapat mengembangkan kemampuan berpikir siswa, melatih keterampilan memecahkan masalah, dan meningkatkan penguasaan materi pelajaran. Duch Allen, and White mengungkapkan bahwa PBM menyediakan kondisi untuk meningkatkan kemampuan pemecahan masalah dan analitis serta memecahkan masalah kompleks dalam kehidupan nyata.

\section{Respon Mahasiswa Terhadap Pembelajaran Biokimia Berbasis SCL} Pada akhir pembelajaran konsep spesiasi diberikan angket kepada mahasiswa di kelas eksperimen untuk mengetahui respon atau tanggapan mahasiswa terhadap pembelajaran berbasis masalah. Angket yang dibuat meliputi 6 indikator yang kemudian dikembangkan menjadi beberapa pertanyaan.

Hasil analisis menunjukkan $61 \%$ mahasiswa memberikan respon positif atau mempunyai ketertarikan terhadap Pembelajaran berbasis SCL, dan 75\% mahasiswa menunjukkan minatnya belajar menggunakanPembelajaran berbasis SCL, respon positif ini mendukung mahasiswa menumbuhkan motivasinya dalam mempelajari konsep protein. Hal ini dapat dilihat pada proses pembelajaran mahasiswa menunjukkan sikap yang antusias dalam proses menemukan permasalahan, mencari solusi alternatif dari berbagai sumber untuk menyelesaikan permasalahan dan memutuskan solusi terbaik. Melalui permasalahan yang dihadirkan dalam pembelajaran mahasiswa dilatih untuk mengkonstruksi dan menemukan konsepnya sendiri, sehingga konsep tersebut akan lebih bertahan lama dalam ingatannya. Sesuai dengan hasil analisis respon mahasiswa sekitar 70\% memberikan respon positif bahwa Pembelajaran berbasis SCL dapat meningkatkan penguasaan konsep mahasiswa.

Hasil analisis selanjutnya adalah mahasiswa memberikan respon positif sebesar $75 \%$ menyetujui bahwa Pembelajaran berbasis SCL dapat meningkatkan kemampuan pemecahan masalahnya pada konsep protein. Dalam pembelajaran berbasis SCL mahasiswa diberikan permasalahan yang nyata dan mahasiswa dilatih untuk mempergunakan kemampuan berpikirnya untuk menyelesaikan permasalahan tersebut. Cara menyelesaikan masalah juga didasarkan pada cara berpikir ilmiah, sehingga solusi untuk menyelesaikan masalah adalah solusi terbaik. Dalam proses pebelajaran mahasiswa melakukan tahapan-tahapan dalam proses yang menunjukkan kemampuan pemecahan masalah, yaitu Mahasiswa melakukan klarifikasi dasar terhadap permasalahan, mengumpulkan informasi dasar, membuat inferensi, membuat klarifikasi lanjut dan membuat serta mengkomunikasikan kesimpulan yang terbaik.

Kondisi pembelajaran tersebut sesuai pendapat Gallagher (1997), tujuan utama PBM dicirikan dengan pembelajaran yang diorientasikan pada penguasaan kemampuan daripada perolehan pengetahuan. PBM menganut pandangan kontruktivisme dalam pembelajaran dan 
memberikan kesempatan siswa untuk mengembangkan kemampuan pemecahan masalah dan evaluatif melalui analisis masalah nyata dalam kehidupan sehari-hari (Smith, 1995). PBM juga akan meningkatkan kemampuan berpikir dan kemampuan belajar serta kemampuan kognitif lainnya pada siswa. Hmleo \& Silver (2004) mengemukakan bahwa PBM didesain untuk membantu siswa membangun dasar pengetahuan yang luas dan fleksibel, mengembangkan selfdirected learning, dan membangun motivasi instrinsik dalam belajar.

Pembelajaran sains dengan menggunakan model PBM memfokuskan pada masalah yang dipilih sehingga siswa tidak saja mempelajari konsep-konsep yang berhubungan dengan masalah tetapi juga metode ilmiah untuk memecahkan masalah tersebut. Oleh sebab itu, siswa tidak saja harus memahami konsep yang relevan dengan masalah yang menjadi pusat perhatian, tetapi juga memperoleh pengalaman belajar yang berhubungan dengan kemampuan menerapkan metode ilmiah dalam pemecahan masalah dan menumbuhkan pola berpikir tingkat tinggi. Respon positif mahasiswa bahwa SCLdalam hal ini menggunakan model PBM dapat meningkatkan kemampuan pemecahan masalah mahasiswa. Sesuai dengan kelebihan PBM diantaranya adalah Pemecahan masalah dapat merangsang kemampuan peserta didik untuk menemukan pengetahuan baru bagi mereka, dapat meningkatkan aktivitas belajar peserta didik, dapat membantu peserta didik untuk menerapkan pengetahuan mereka dalam kehidupan sehari-hari, PBM dapat membantu peserta didik untuk berlatih berpikir dalam menghadapi sesuatu dan PBM dapat mengembangkan kemampuan pemecahan masalah dan kemampuan menyesuaikan dengan pengetahuan baru.
Teori-teori konstruktivis tentang belajar, yang menekankan pada kebutuhan pelajar untuk menginvestigasi lingkungannya dan mengonstruksikan pengetahuan yang secara personal berarti, memberikan dasar teoritis untuk PBM. Dengan demikian, hasil penelitian ini memperkuat teori-teori konstruktivis tentang belajar seperti Piaget, Vygotsky juga John Dewey ( 2008) yang menyatakan bahwa PBM membuat siswa berpikir, memecahkan masalah, dan menjadi pembelajar mandiri, selain itu PBM juga dapat meningkatkan penguasaan konsep mahasiswa.

\section{SIMPULAN dan SARAN}

\section{A. Simpulan}

Berdasarkan hasil penelitian, diperoleh beberapa kesimpulanyaitu :

1. Terdapat perbedaan hasil antara tes awal dan tes akhir pada keterampilan pemecahan masalah sebelum dan sesudah pembelajaran biokimia berbasis Student Center Learning (SCL).

2. Terdapat pengaruh yang signifikan dari pembelajaran biokimia berbasis Student Center Learning (SCL) terhadap kemampuan pemecahan masalah mahasiswa.

3. Tingkat ketuntasan pemecahan masalah mahasiswa sebesar 70,8 \%. $29,2 \%$ mahasiswa belum mencapai ketuntasan belajar. Tingkat ketuntasan penguasaan konsep mahasiswa sebesar $71,25 \%$. $28,75 \%$ mahasiswa belum mencapai ketuntasan belajar.

4. Respon positif dari mahasiswa terhadap penerapan pembelajaran biokimia berbasis Student Center Learning (SCL) terhadap keterampilan pemecahan masalah mahasiswa 


\section{B. Saran}

Berdasarkan hasil temuan dari penelitian, berikutbeberapa sarangunamelengkapipenelitianini,diant aranyaadalah:

1. Padasaatpembelajaran,diperlukan manajemenwaktuyangbaikantaratiap tahapan padapembelajaran berbasis SCL.

Kondisiawalpembelajaranperlulebihdit ekankan lagi,diskusi sebaiknyamelibatkanseluruh mahasiswa, dandiakhirkegiatanperlu dilakukanpenguatankonsepdanprinsipk egiatandalamSCL.

2. Pada saat menentukan permasalahan dalam kegiatan pembelajaran sebaiknya diarahkan pada permasalahan yang ada di lingkungan sekitar mahasiswa agar mudah dipahami.

3. Respon positif siswa terhadap pembelajaran berbasis SCL pada konsep protein memberikan peluang penggunaan pembelajaran berbasis SCL pada pembelajaranbiologikonseplain.

4. Penelitian yang dilaksanakan oleh peneliti lain diperlukan sebagai masukan dalam penelitian ini. Hal ini karena adanya kemungkinan perbedaan pengetahuan, cara mengajar dan pengalaman akan mempengaruhi hasil penelitian.

\section{DAFTAR PUSTAKA}

Anderson, L.W. \& D.R. Krathwohl. ( 2001). Kerangka Landasan Untuk Pembelajaran, Pengajaran Dan Asesmen Agung Prihantoro (penerjemah). Yogyakarta. Pustaka Pelajar.

Arends, R.I. (2008). Learning to Teach, seventh edition. Mc Graw-Hill Companies. New York.

Arikunto, S. (2007). Dasar-Dasar Evaluasi Pendidikan. Jakarta: Bumi Aksara.

Aunurrahman. (2009). Belajar Dan Pembelajaran. Bandung. Alfabeta.

Bilgin, I dan Senocak, E. (2009). : "The Effect of Problem Based Learning Instruction on University Students'
Performance of Conceptual and Cuantitative Problems". Eurasial Journal of Mathematics, Science \& Technology Education Vol. 5(2), pp. 153-164.

Colby, D. (1989). Ringkasan Biokimia. Jakarta : EGC

Dahar, R.W. (1996). Teori-Teori Belajar: Jakarta, Penerbit Erlangga.

Delisle, R. (1997). How to Use ProblemBased Learning in the Classroom. USA : ASCD.

Eishu, N danTanaka, Y. (2010). :'ProblemBased Learning in a Multidisciplinary group enhances clinical Decision Making by Medical Student : A Randomized kontrolled Trial". J Med Dent Sci $57: 109-118$.

Elaine H. J. (2011). : "Is learning in problem-based learning cumulative?". Adv in Health Sci Educ 16:449-464.

Ennis, R.H. (1996). Critical Thinking. New York: New York Times Company.

Folmer, V. dan Nilda B. (2009). :"Experimental activities based on ill-structuredproblems improve Brazilian school students'understanding of thenature of scientific knowledge". Revista Electrónica de Enseñanza de las Ciencias Vol.8 $N^{\circ} 1$.

Fraenkel,J.R\& Wallen,N.E. (2007). How to Design and Evaluate Reseach in Education. San Francisco : McGraw-Hill Higer Education.

Hidayat, T. (2013). Problem Based Learning (PBM) di Biologi (Best Practice). Bandung : Jurusan Pendidikan Biologi UPI.

Jhonson L.V. \& Jhonson, A.B. 1970, Classroom Management. London: MacMillan.

Joyce B, Weil M, Calhoun E. (2009). Models Of Teaching. Ahmad F, Ateilla M (penerjemah). Yogyakarta. Pustaka Pelajar.

Kunandar. (2009). Dosen Profesional: implementasi Kurikulum Tingkat Satuan Pendidikan dan Munir. (2008). Prinsip Dasar 
Pembelajaran Aktif. Bandung: UPI dan CV. Alfabeta.

Lehninger. (1988). Dasar-Dasar Biokimia. Jakarta : Erlangga.

Nachamma, S.N. dan Schmidt, H.G. (2011). "Characteristics of Problems for Problem-Based Learning: The Students' Perspective". Interdisciplinary Journal of Problem-based LearningVol. 5: Iss. 1, Article 3.

Sagala,S., (2010). Konsep dan Makna Pembelajaran, Bandung, Alfabeta.

Sanjaya, W. (2008). Strategi Pembelajaran Berorientasi Standar Proses Pendidikan. Jakarta: Putra Grafika.

Serene S. Y., Jerome I. Rotgans.,Elaine H. J. Yew.,Henk G. Schmidt. (2011). : "Effect of worksheet scaffolds on student learning in problem-based learning". Adv in Health Sci Educ 16:517-528.

Slameto. (2010). Belajar dan FaktorFaktor yang Mempengaruhi. Jakarta : Rineka Cipta.

Stiggins, R.J. (1994).Student-Centered Classroom Assessment. New York: Macmillan.
Sugiyono. (2012). Statistika untuk Penelitian. Bandung : Alvabeta cv.

Sukaesih, S (2010). Pembelajaran Berbasis Praktikum dengan Menerapkan Asesmen Tes Lisan Pada Topik Keanekaragaman hayati Untuk mengembangkan Kemampuan Berpikir Kritis dan Sikap Ilmiah Mahasiswa. Tesis UPI Bandung : Tidak Diterbitkan.

Suprijono, A. (2012). Cooperative Learning. Surabaya : Pustaka Pelajar.

Trianto. (2007). Model-model Pembelajaran Inovatif Berorientasi Konstrutivistik: Konsep, Landasan Teoritis-Praktis Dan Implementasinya. Jakarta. Prestasi Pustaka.

Yenice, N. (2011). : "Investigating preservice Science Teachers' Critical Thinking Dispositions and Problem Solving Skills in Terms of Different Variabels". Educational Research and Reviews Vol.6(6),pp.497-508. 